\begin{tabular}{l} 
Final Report Certification \\
for \\
CRADA Number $\quad$ NFE-08-01374 \\
\hline
\end{tabular}

Between

UT-Battelle, LLC

and

Carpenter Technology Comporation

(Participant)

Instructions:

Mark the appropriate statement in 1a or 1b below with an "IX." Refer to the articles in the CRADA terms and conditions governing the identification and marking of Protected CRADA Information (PCI).

If no $\mathrm{PCl}$ is identified, the report will be distributed without restriction. If $\mathrm{PCl}$ is identified, the report distribution will be limited in accordance with the CRADA terms and conditions governing release of data. In all cases items 2 and 3 must be true. That is, the report cannot contain Proprietary Information and a disclosure must be filed prior to release of the report.

This certification may either be made by using this form or may be made on company letterhead if the Participant desires. A faxed copy of this completed form is acceptable.

The following certification is made for the subject final report:

1. (a) $\square$ The final report contains information that qualifies as "Protected CRADA Information" (PCI). The PCl legend is printed on the report cover, and the $\mathrm{PCl}$ is clearly identified.

OR

(b) The final report does not contain "Protected CRADA Information." The "Approved for Public Release" legend is printed on the report cover.

2. The final report does not contain Proprietary Information.

3. By the signature below, the Participant has no objection to the public distribution of the final report due to patentable information.

For the Participant:
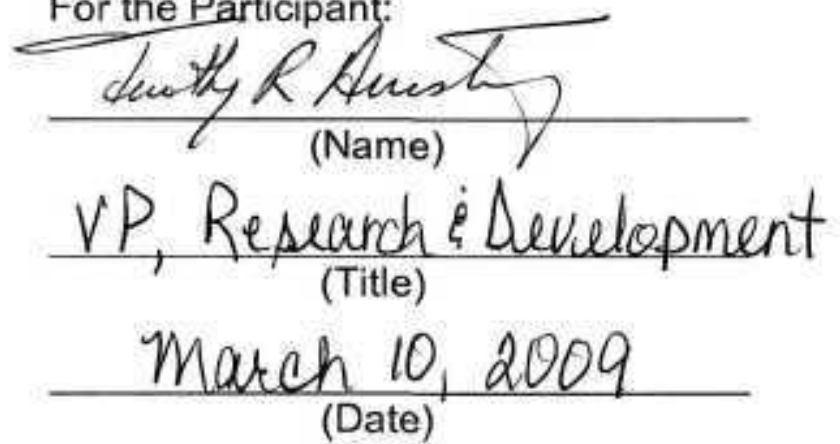


\section{CRADA FINAL REPORT}

\section{CRADA NFE-08-01374 Manufacture of Alumina-Forming Austenitic Stainless Steel Alloys by Conventional Casting and Hot-Working Methods}

\section{DOCUMENT AVAILABILITY}

Reports produced after January 1, 1996, are generally available free via the U.S. Department of Energy (DOE) Information Bridge. Web site http://www.osti.gov/bridge Reports produced before January 1, 1996, may be purchased by members of the public from the following source.

National Technical Information Service

5285 Port Royal Road

Springfield, VA 22161

Telephone 703-605-6000 (1-800-553-6847)

TDD 703-487-4639

Fax 703-605-6900

E-mail info@ntis.fedworld.gov

Web site http://www,ntis.gov/support/ordernowabout.htm

Reports are available to DOE employees, DOE contractors, Energy Technology Data Exchange (ETDE) representatives, and International Nuclear Information System (INIS) representatives from the following source.

Office of Scientific and Technical Information

P.O. Box 62

Oak Ridge, TN 37831

Telephone 865-576-8401

Fax 865-576-5728

E-mail reports@adonis.osti.gov

Web site http://www.osti.gov/contact.html

This report was prepared as an account of work sponsored by an agency of the United States Government. Neither the United States Government nor any agency thereof, nor any of their employees, makes any warranty, express or implied, or assumes any legal liability or responsibility for the accuracy, completeness, or usefulness of any information, apparatus, product, or process disclosed, or represents that its use would not infringe privately owned rights. Reference herein to any specific commercial product, process, or service by trade name, trademark, manufacturer, or otherwise, does not necessarily constitute or imply its endorsement, recommendation, or favoring by the United States Government or any agency thereof. The views and opinions of authors expressed herein do not necessarily state or reflect those of the United States Government or any agency thereof. 


\title{
CRADA NFE-08-01374 Manufacture of Alumina-Forming Austenitic Stainless Steel Alloys by Conventional Casting and Hot-Working Methods
}

\author{
${ }^{1}$ M.P. Brady, 'Y. Yamamoto, and ${ }^{2}$ J.H. Magee \\ ${ }^{1}$ Materials Science and Technology Division, Oak Ridge National laboratory, Oak Ridge, TN \\ USA 37831-6115 \\ ${ }^{2}$ Carpenter Technology Corporation, PO Box 14662, Reading, Pa USA 19612-4662
}

Work performed July 2008-Jan 2009

\begin{abstract}
Oak Ridge National Laboratory (ORNL) and Carpenter Technology Corporation (CarTech) participated in an in-kind cost share cooperative research and development agreement (CRADA) effort under the auspices of the Energy Efficiency and Renewable Energy (EERE) Technology Maturation Program to explore the feasibility for scale up of developmental ORNL aluminaforming austenitic (AFA) stainless steels by conventional casting and rolling techniques. CarTech successfully vacuum melted $30 \mathrm{lb}$ heats of four AFA alloy compositions in the range of $\mathrm{Fc}-(20-25) \mathrm{Ni}-(12-14) \mathrm{Cr}-(3-4) \mathrm{Al}-(1-2.5) \mathrm{Nb}$ wt.\% base. Conventional hot/cold rolling was used to produce 0.5 " thick plate and 0.1 " thick sheet product. ORNL subsequently successfully rolled the 0.1 " sheet to $4 \mathrm{mil}$ thick foil. Long-term oxidation studies of the plate form material were initiated at 650,700 , and $800^{\circ} \mathrm{C}$ in air with 10 volume percent water vapor. Preliminary results indicated that the alloys exhibit comparable (good) oxidation resistance to ORNL laboratory scale AFA alloy arc casting previously evaluated. The sheet and foil material will be used in ongoing evaluation efforts for oxidation and creep resistance under related CRADAs with two gas turbine engine manufacturers. This work will be directed to evaluation of AFA alloys for use in gas turbine recuperators to permit higher-temperature operating conditions for improved efficiencies and reduced environmental emissions.
\end{abstract}

\section{Statement of Objectives}

AFA alloy properties to date have been obtained from small laboratory scale arc-castings made at ORNL. The goal of the ORNL-CarTech CRADA was to establish the viability for producing plate, sheet and foil of the AFA alloys by conventional casting and hot working approaches as a first step towards scale up and commercialization of the AFA alloys. The AFA alloy produced under this effort will then be evaluated in related CRADAs with two gas turbine engine manufacturers for gas turbine recuperator applications.

\section{Benefits to the Funding DOE Office's Mission}

The ORNL AFA stainless steels are a new class of high-temperature alloy family with $\geq 50$ $200^{\circ} \mathrm{C}\left(\sim 100-400^{\circ} \mathrm{F}\right)$ increased upper-temperature oxidation (corrosion) limit over that of conventional stainless steels. AFA steels deliver these uniquely superior properties without sacrificing the typical lower cost, formability and weldability of conventional stainless steels. Due to their outstanding oxidation resistance, which results from the formation of a protective 
aluminum oxide (alumina, $\mathrm{Al}_{2} \mathrm{O}_{3}$ ) surface layer, AFA stainless steels can be used at higher temperatures and for longer times than conventional chromium-oxide (chromia, $\mathrm{Cr}_{2} \mathrm{O}_{3}$ )-forming stainless steels in highly-corrosive operating environments. These unique attributes of AFA steels make them highly desirable in a wide range of energy production and chemical industry applications, where implementation of more durable, higher-temperature capable materials can result in significant savings in cost and energy, and reductions in environmental emissions. Thus, they are highly relevant to the DOE EERE program mission.

\section{Technical Discussion of Work Performed by All Parties}

Four $30 \mathrm{lb}$. VIM (vacuum-melted) AFA alloy heats were cast by CarTech as tapered 4"x4" $\mathrm{x}$ 8.5 " long ingots. Alloy chemistries are shown in Table 1. The ingots were heated in a reducing (natural gas) atmosphere at $1200^{\circ} \mathrm{C}$ for 4 hours and double-end forged (reheated 20 minutes to forge hot top ends) to 4.5 " $\mathrm{x} 1.125$ " $\mathrm{x}$ length. The hot tops were cut off and two 6 " and two 4 " pieces were cut from the forged slab for further processing. These pieces were milled on all four sides to 4.25 " $\mathrm{X} \mathrm{1".} \mathrm{A} \mathrm{4"} \mathrm{piece} \mathrm{from} \mathrm{each} \mathrm{heat} \mathrm{was} \mathrm{used} \mathrm{as} \mathrm{trial} \mathrm{hot} \mathrm{rolling} \mathrm{specimens} \mathrm{to} \mathrm{set-}$ up rolling passes. The milled slabs were heated in air at $1200^{\circ} \mathrm{C}$ for $1 \mathrm{~h}$. Eight $6^{\prime \prime}$ pieces were hot rolled to .600 " thick. Four 4"pieces were hot rolled to .270 " thick (alloy OC-1, heat 1591 was hot rolled to $.310^{\prime \prime}$ thick). The hot rolled material was then annealed in air at $1200^{\circ} \mathrm{C}$ for 30 minutes and air cooled. The eight .600 " thick plates ( 2 per alloy type) were milled to $0.508^{\prime \prime} \mathrm{x}$ $4.1875 " \mathrm{n} 10-11.5$ " lengths. The four 0.270 " thick strips ( 1 per alloy) were milled to 0.190 " thick and cold rolled to 0.098 "x 4.25 "x 24-33" lengths.

A photograph of the AFA alloy plate and sheet material manufactured by CarTech is shown in Fig. 1. The initially targeted application of AFA alloys is for use in gas turbine recuperators. Subsequent processing of the AFA alloy sheet by ORNL was successful in producing 4 mil thick AFA alloy foil (Fig. 1). Creep and oxidation evaluation of the AFA foil will be pursued under follow-on CRADAs with two gas turbine manufacturers.

Oxidation data for AFA alloy plate material produced by CarTech is shown in Fig. 2. All four AFA alloys showed excellent behavior in cyclic oxidation at 650 and $700^{\circ} \mathrm{C}$ in air with 10 volume percent water vapor (400-900 total hours accumulated thus far), a test condition which is designed to simulate the detrimental effects of water vapor encountered in combustion environments $\left(650-700^{\circ} \mathrm{C}\right.$ is the targeted recuperator inlet temperature range for higherefficiency gas turbines). This is a key result because the alloys contained additions of $\mathrm{Ti}$ and $\mathrm{V}$ (Table 1) to simulate impurity levels expected in high-volume commercial production using lowcost scrap metal feedstock ( $\mathrm{Ti}$ and $\mathrm{V}$ can degrade oxidation resistance in AFA alloys).

At $800^{\circ} \mathrm{C}$ in air with 10 volume percent water vapor (Fig. 2), alloys OC-1 and OC-3 exhibited a transition to rapid, nonprotective Fe-oxide nodule formation after only a few hundred hours exposure. In contrast, alloys $\mathrm{OC}-2$ and $\mathrm{OC}-4$ exhibited good oxidation resistance and low mass gains consistent with protective alumina scale formation out to $900 \mathrm{~h}$ of ongoing exposure (Fig. 2). The superior oxidation resistance of alloys $\mathrm{OC}-2$ and $\mathrm{OC}-4$ was consistent with previously observed AFA composition-oxidation-temperature trends. The poor behavior of $\mathrm{OC}-1$ at $800^{\circ} \mathrm{C}$ was somewhat unexpected, as arc-cast material of similar composition tolerated over $4000 \mathrm{~h}$ of exposure under these conditions prior to initiation of Fe-oxide nodules. This lesser oxidation 
behavior is likely a consequence of the borderline nature of the $\mathrm{OC}-1$ composition at $800^{\circ} \mathrm{C}$ in water vapor. All ORNL AFA compositions exhibit a transition from protective alumina layer formation to internal oxidation of Al (and nonprotective oxidation behavior) if the oxidation temperature is raised too high, i.e. they have a defined upper-temperature performance limit for their good oxidation resistance. (This is a consequence of the relatively low levels of $\mathrm{Al}$ and $\mathrm{Cr}$ used in AFA alloys to achieve the balance mechanical properties with oxidation resistance). The oxidation studies will continue for both plate and foil material under related CRADAs with gas turbine manufacturers to confirm that oxidation resistance at 650 and $700^{\circ} \mathrm{C}$ is maintained over long-term exposures.

\section{Subject Inventions (As defined in the CRADA)}

No new intellectual property (IP) was generated under this CRADA.

\section{Commercialization Possibilities}

The results obtained under this CRADA indicate good potential to commercialize the AFA stainless steels. The alloys were found by CarTech to be readily amenable to conventional austenitic stainless steel manufacturing techniques, and the resultant alloy material showed good oxidation behavior, comparable to that observed with laboratory scale arc-cast material produced by ORNL. ORNL also demonstrated suitability for production of AFA alloy foil, the product form needed for the gas turbine recuperator component to be evaluated under CRADAs with two gas turbine manufacturers.

\section{Plans for Future Collaboration}

An abstract for a joint CARTECH/ORNL presentation and paper was submitted to the Stainless Steel World 2009 Conference \& Expo in Maastricht, The Netherlands, November 10th - 12th 2009. Continued long-term oxidation and creep studies of AFA alloy plate and foil will be pursued under related CRADAs with two gas turbine manufacturers.

\section{Conclusions}

1) AFA stainless steels are amenable to conventional vacuum casting, hot- and cold- rolling processing.

2) Levels of Ti and $\mathrm{V}$ impurities expected in high-volume commercial production using low-cost scrap metal feedstock can be tolerated in AFA alloys without significant detriment in oxidation resistance.

3) The AFA alloys show good potential for scale up and commercialization.

\section{Acknowledgements}

This work was funded under the DOE EERE Technology Maturation Program. ORNL is managed by UT-Battelle, LLC for the US DOE under contract DE-AC05-00OR22725. 
Table 1- Analyses of as-cast AFA alloy heats provided CARTECH (weight percent, wt.\%).

\begin{tabular}{|l|l|l|l|l|}
\hline Heat No/Alloy & $1591(\mathrm{OC}-1)$ & $1593(\mathrm{OC}-2)$ & $1595(\mathrm{OC}-3)$ & $1597(\mathrm{OC}-4)$ \\
\hline $\mathrm{C}$ & .109 & .051 & .104 & .101 \\
\hline $\mathrm{Mn}$ & 1.98 & 1.98 & 1.97 & 1.97 \\
\hline $\mathrm{Si}$ & .14 & .14 & .14 & .14 \\
\hline $\mathrm{P}$ & .016 & .013 & .014 & .013 \\
\hline $\mathrm{S}$ & .0012 & .0010 & .0012 & .0009 \\
\hline $\mathrm{Cr}$ & 14.24 & 14.26 & 12.00 & 13.96 \\
\hline $\mathrm{Ni}$ & 20.03 & 24.98 & 19.96 & 25.03 \\
\hline $\mathrm{Mo}$ & 1.99 & 1.98 & 1.99 & 1.98 \\
\hline $\mathrm{Cu}$ & .51 & .51 & .51 & .51 \\
\hline $\mathrm{W}$ & .97 & .96 & .97 & .95 \\
\hline $\mathrm{V}$ & .04 & .04 & .04 & .04 \\
\hline $\mathrm{Ti}$ & .05 & .05 & .05 & .05 \\
\hline $\mathrm{Al}$ & 3.02 & 3.04 & 4.06 & 3.55 \\
\hline $\mathrm{Nb}$ & 2.53 & 1.03 & 1.54 & 2.53 \\
\hline $\mathrm{B}$ & .0068 & .0069 & .0073 & .0008 \\
\hline $\mathrm{N}$ & .0005 & .0005 & .0004 & $<.0010$ \\
\hline $\mathrm{Fe}$ & $\mathrm{Bal}$ & $\mathrm{Bal}$ & $\mathrm{Bal}$ & $\mathrm{Bal}$ \\
\hline
\end{tabular}



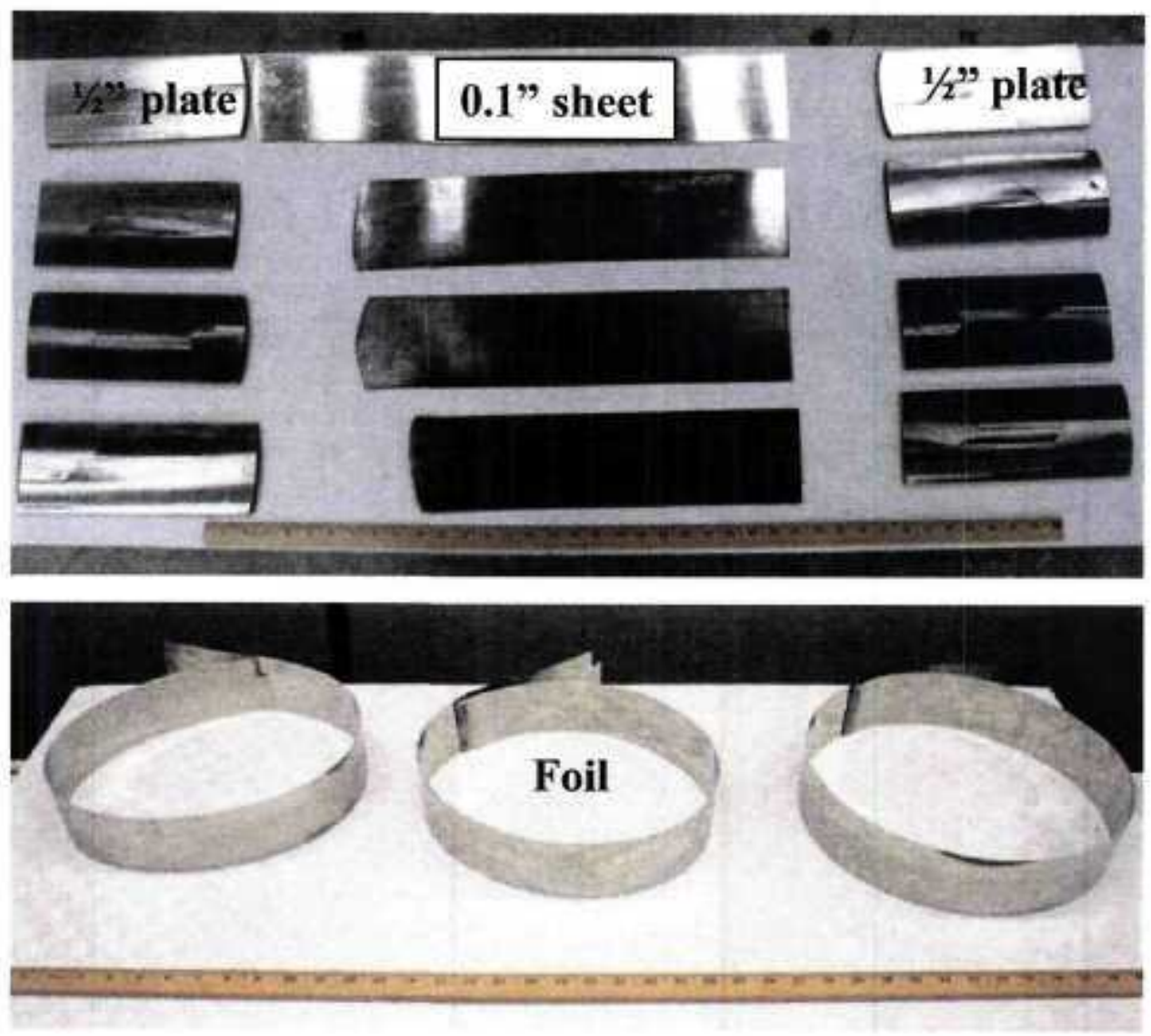

Fig. 1- AFA steel 1/2" thick plate, 0.1 "thick sheet, and 4 mils thick foil product forms made by Car'Tech and ORNL under this CRADA. 
a)
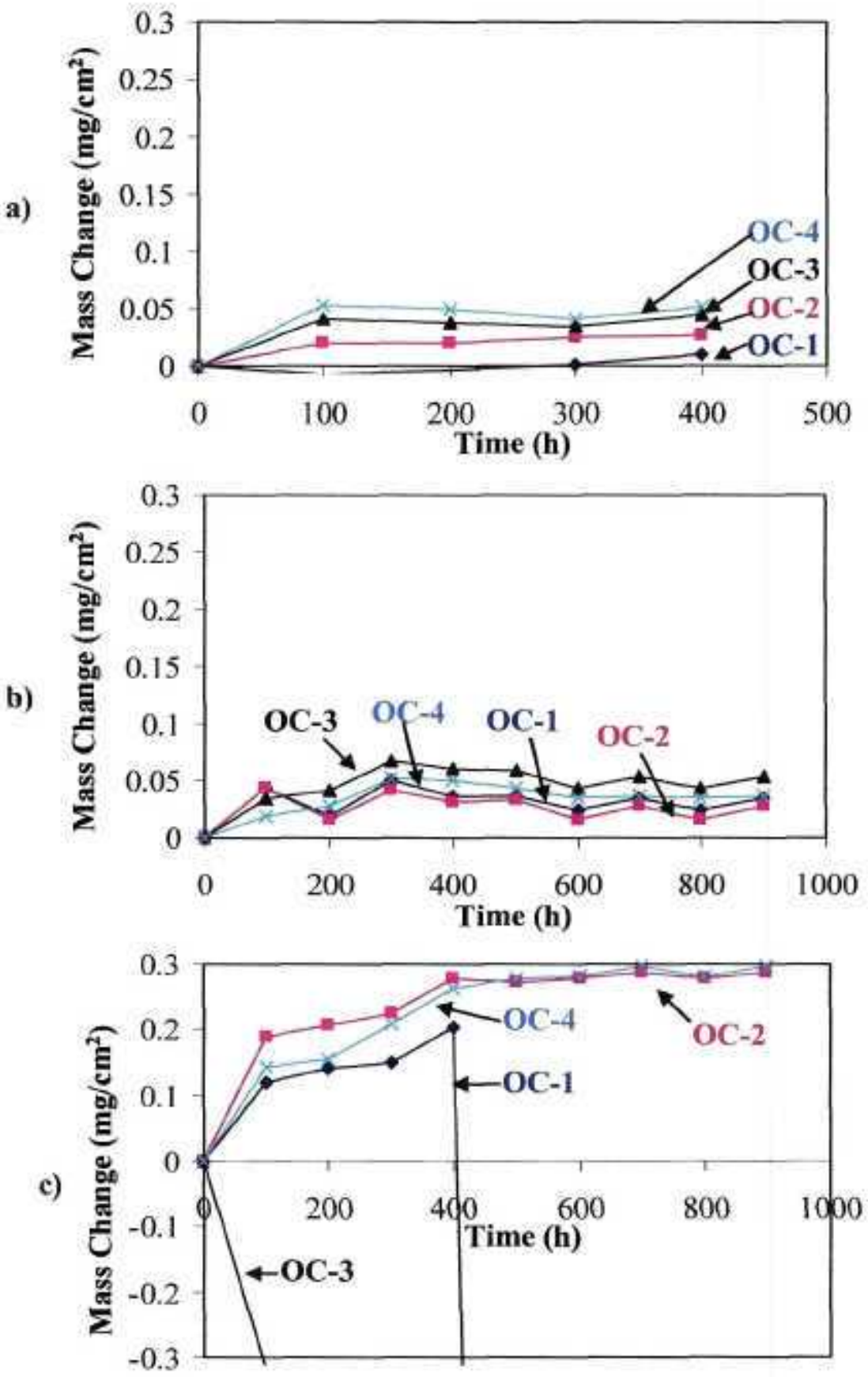

Fig. 2- Oxidation data for $20 \mathrm{~mm} \times 10 \mathrm{~mm} \times 1 \mathrm{~mm}$ coupons from 0.5 " plate of AFA alloys OC-1, OC-2, OC-3, and OC- -4 manufactured by CarTech. a) $650^{\circ} \mathrm{C}$ in air with 10 volume percent water vapor; b) $700^{\circ} \mathrm{C}$ in air with 10 volume percent water vapor; c) $800^{\circ} \mathrm{C}$ in air with 10 volume percent water vapor. 